\title{
Correction To: Desertification Risk Assessment of Sand Dunes in Middle Egypt: A Geotechnical Environmental Study
}

\author{
El-Sayed Sedek Abu Seif ${ }^{1,2} \cdot$ Mohamed H. El-Khashab ${ }^{2}$
}

Published online: 16 May 2019

(c) King Fahd University of Petroleum \& Minerals 2019

\section{Correction to: \\ Arabian Journal for Science and Engineering (2019) \\ 44:357-375 \\ https://doi.org/10.1007/s13369-018-3343-7}

In the original publication the grant number is incorrectly published. The correct grant number should be, Grant number D-071-145-1439.

The original article can be found online at https://doi.org/10.1007/ s13369-018-3343-7.

El-Sayed Sedek Abu Seif esmansor@kau.edu.sa

1 Faculty of Earth Sciences, King Abdulaziz University, Jeddah, Saudi Arabia

2 Geology Department, Faculty of Science, Sohag University, P.O. Box 82524, Sohâg, Egypt 